\title{
Towards an understanding of the costs of fire
}

Amanda G. Henry ${ }^{1,2 *}$, Thomas Büdel ${ }^{2,3}$, Pierre-Louis Bazin ${ }^{4,5,6}$

${ }^{1}$ HARVEST project, Faculty of Archaeology, Leiden University, Leiden, Netherlands

$10 \quad{ }^{2}$ Plant foods in hominin dietary ecology research group, Max Planck Institute for Evolutionary Anthropology, Leipzig, Germany

${ }^{3}$ Institute for Infectious Diseases, University of Bern, Bern, Switzerland

${ }^{4}$ Department of Neurology, Department of Neurophysics, Max Planck Institute for Cognitive and Brain Sciences, Leipzig, Germany

$15{ }^{5}$ Spinoza Center for Neuroimaging, Amsterdam, The Netherlands

${ }^{6}$ Netherlands Institute for Neuroscience, Amsterdam, The Netherlands

* Corresponding Author

E-mail: a.g.henry@arch.leidenuniv.nl 


\begin{abstract}
The ability to produce fire at will and to maintain it for a long duration is considered one of the major advances in human evolution. The exact process by which hominins first learned to use and to

25 create fire is still hotly debated, with some arguing for a sudden transformative event that was quickly followed by a biological and cultural dependence on fire, such as a reliance on the extra calories saved through cooking food and an external source of heat. Others suggest that the 'domestication' of fire was a long and drawn-out process, with hominins using fire when it was available on the landscape but perhaps not having the ability to produce fire until much later in human history. In this paper we

30 propose a third option, that fire should be considered like other technologies - that is, it certainly comes with benefits but also with costs, and that hominins functioned as optimal foragers who chose to use this tool only when the costs were less than the benefits. The potential benefits of fire have been welldescribed in other publications. Here we discuss in detail the various kinds of costs associated with fire and how these costs could, and do, structure human fire-use behavior. We then describe a small

35 experiment to 'put some numbers on' the potential costs of fire, by quantifying one of the most expensive costs (fuel collection) and comparing it to one of the most-praised benefits (cooking of food). The results suggest that the costs of fuel collection are very high in less-forested environments, and that excessively large amounts of cooked foods are needed to match the total costs of fuel collection and the act of cooking. Overall, the costs of fire can be quite high and must be considered when proposing models for pre-modern human adoption and regular use of fire technologies.
\end{abstract}

Keywords: fire; optimal foraging; cost:benefit ratio; fuel

\title{
1. Introduction
}

45 Fire is widely considered as a seminal invention in human history and some authors have argued that the benefits of fire are so numerous and significant that as soon as hominins developed the ability to create fire it very quickly became an essential part of the hominin adaptive suite to the point that hominins were no longer able to live without it (Barkai et al., 2017; Wrangham and ConklinBrittain, 2003). To borrow the terminology used in studies of the evolution of hominin locomotion, this

50 argument states that humans very quickly went from "habitual" fire users to "obligate" fire users (sensu Harcourt-Smith, 2007). Fire is widely credited with 'freeing' enough calories (by making food easier to digest) to drive brain expansion, decreases in gut size, and reduction in tooth size (Boback et al., 2007; Zink et al., 2014). The heat from fire can reduce the caloric requirements for maintaining core body temperature (Scholander et al., 1958). Fire also provides benefits by repelling predators (Wiessner as

55 cited in Wrangham and Carmody, 2010), by providing a means to create and improve tools [e.g. heattreating stones to improve their physical properties (Domanski and Webb, 1992), and creating adhesives to make compound tools (Mazza et al., 2006)]. Furthermore, the light from fire can facilitate the performance of fitness-enhancing behaviors after dark, including domestic tasks like tool production and repair, and social interactions (Dunbar and Gowlett, 2014; Wiessner, 2014).

While there are undoubtedly strong benefits to fire use, the assumption that fire became an essential component of the hominin niche immediately after hominins first began to use fire is problematic for several reasons. First, as has been highlighted many times by others, the record of fire use in the archaeological record is spotty even as recently as 400ka (Roebroeks and Villa, 2011), and the nature of the interaction between humans and fire likely changed through time (Sandgathe, 2017).

Second, the presumed benefits of fire may be over-estimated given that they have largely been established using evidence from modern humans, who are likely poor analogues for earlier hominins. 
Further, the benefits of fire likely varied significantly among environments, changing the overall cost to benefit ratios. Finally, the potential costs of fire have not been fully explored.

A recent Wenner Gren Symposium on "Fire and the Genus Homo" summarized recent evidence

70 that early hominins and fire remains appear in the same sites on the landscape quite early in human evolution (e.g., Gao et al., 2017; Hlubik et al., 2017). However, it remains difficult to determine the type of interaction hominins had with fire - did they tolerate fire and perhaps prefer burned landscapes, as do the chimpanzees at Fongoli (Pruetz and Herzog, 2017)? Did they regularly bring or build fires to the same place on the landscape, such as at Gesher Benot Ya'aqov (Alperson-Afil, 2017)? Did they

75 have the ability to regularly construct and control the burning characteristics of a fire, as suggested by the constructed hearths at Abri Blanchard (White et al., 2017)? One of the conclusions of this symposium is that the archaeological record for hominin interaction with fire is very discontinuous for a long time after the first appearance of hominin-associated fire remains, and that it remains difficult to ascertain whether these early records reflect hominin toleration, use, maintenance, or control of fire

80 (Sandgathe, 2017). Given this recent coverage of the early record of human fire, we will leave aside this question and focus instead on the latter three problems mentioned above.

The goal of this paper is to argue that while modern humans are adapted to fire to the point of being almost unable to live without it (i.e. obligate fire users), the same cannot and should not be assumed for earlier hominins, even if they did occasionally or even regularly use fire. An approach that supposes a 'long prehistory of fire' as elucidated by Chazan (2017), allows us to look more clearly at the behavioral evidence for the use of fire of early hominins and to ask when, why, and in what conditions they used fire. We can gain a greater understanding of the kinds of decisions that hominins were making and by using an economic framework that incorporates the costs and benefits of fire we can gain a better insight into the kinds of things that hominins found most important, whether that be

90 time budgets, calorie budgets, or other currencies such as social interactions. The theoretical justification for using an economic framework was first explored in a paper presented by one of us as part of the Wenner Gren Symposium (Henry, 2017). That paper focused on cooking and fire use by Neanderthals, and how an economic approach might help explain the discontinuous record seen by Dibble, Sandgathe and colleagues (Dibble et al., 2017; Sandgathe et al., 2011). In this paper, we present one example of how such an economic analysis might work, by comparing one potential cost of fire the energetic cost of fuel collection - to one potential benefit from fire - the increased availability of calories from cooked food.

\subsection{The benefits of fire for early hominins may be over-estimated}

Many theories about the origin of and investment in fire use focus on its benefits. The value of these benefits is assumed to be the same for the first users of fire as it is for living or recent historical modern human groups (e.g., Carmody and Wrangham, 2009a). For example, these studies have emphasized that living humans are physiologically adapted to the calories from cooked food and the heat provided by burning and argue that early hominins must have quickly become reliant on these advantageous effects. However, there is increasing evidence that modern indigenous groups in fact show a wider range of tolerances to these benefits than previously supposed.

First, a study of the cold adaptations of Australian Aborigines showed that they were able to tolerate sleeping minimally covered in freezing temperatures with no fire, allowing the temperatures of their feet to drop to $12-15^{\circ} \mathrm{C}$ (Scholander et al., 1958). Their physiological adaptation functioned much like the insulative cooling seen among some arctic mammals, in which basal metabolic rate remained static or even dropped during the night, and the core kept warm while the feet and other surface areas 
became cold. In contrast the European participants in the same study slept only intermittently through the night and compensated for the cold by shivering and a raised metabolic rate. The Aborigines

115 showed a physiological adaptation to cold that allowed them to tolerate low temperatures which were extremely uncomfortable and potentially life-threatening to the Europeans.

The second example covers how recent historical human groups, particularly in circum-Arctic populations, processed their food in a fire-limited environments. A recent paper by Speth (2017) details how these groups extensively fermented or intentionally rotted their food, particularly meat and fish.

120 Like cooking, fermentation made the meat easier to digest, reduced harmful bacteria, and provided a means for long-term storage of the food. While Europeans regularly expressed disgust at the smell of these products, they were clearly relished by the Arctic groups who produced them. Because it does not require fuel, which was scarce in the Arctic environments, fermenting was a behavioral adaptation to reduce the reliance on fire while still providing the benefits usually achieved by cooking.

125 Given the ability among living humans to tolerate lower levels of energetic and other benefits from fire, we should anticipate that earlier hominins also had a broader range of physiological adaptations and/or acclimatizations to lower temperatures and uncooked foods. In general, studies that rely on recent living humans as models for past abilities (including this study, see sections 2 and 3 below) are limited in that many aspects of hominin physiology are poorly represented by living and

130 particularly Western, modern humans. Because all modern human groups are obligate fire users, studying their use of fire tells us very little about how this trait evolved and what other kinds of nonobligate interactions with fire may have looked like.

\subsection{Benefits of fire likely vary among environments}

135 Proposals for the earliest adoption of fire tend to ignore how the proposed benefits of fire may vary among environments and habitats, and instead assume a cumulative overwhelming benefit to fire. However, a closer consideration of these benefits suggests that they may not be evenly distributed, and depend highly on the climate and types of foods available.

Cooking is one of the most-praised benefits of fire, yet the value of cooking can vary across

140 habitats. It is generally assumed to provide an energetic benefit by reducing the costs of digestion and by denaturing toxins and breaking down refractive nutritional components like proteins and starches (Carmody and Wrangham, 2009b; Groopman et al., 2015; though see Cornélio et al., 2016 for an opposing view). However, not all foods are cooked for the same reasons, and cooking can provide different benefits for different foods. Hadza foragers in the savanna landscapes around Lake Eyasi of

145 Tanzania rely heavily on plant underground storage organs. Many of these tubers are cooked only briefly (c. $5 \mathrm{~min}$ ), if cooked at all (Marlowe, 2010). One study of the glucose digestibility of these tubers showed that of four species, one had improved digestibility when cooked, two had negligible changes, and one was actually less digestible after cooking (Schnorr et al., 2015). Here, cooking was not used to increase the digestibility of the tubers, but instead to make them easier to peel or possibly to

150 make them tastier. In contrast, many of the tubers available in rainforest environments contain harmful toxins that must be denatured by extensive cooking and processing (Tanno, 1981). One cannot assign the same benefit value to cooked food in these different environments, since clearly in one place cooking is a convenience and in the other it is a necessity to make the plants edible.

\subsection{There are many potential costs to fire, many of which can be quite high}

Despite focus on the positive aspects of fire, it is not free. There are a variety of costs for any use of fire, including time and energy spent collecting fuel, time spent maintaining and possibly defending the fire, and time lost from performing other behaviors (Ofek, 2001; Twomey, 2013). Fire 
becomes a shared good, which is at risk from free-loaders who can increase the costs of fire and decrease the benefits by stealing the space at the fire or the food cooked upon it (Ofek, 2001; Twomey, 2013; Wrangham et al., 1999). Sitting by a fire and consuming cooked foods also can have health costs, due to the nutrient-reducing and potentially carcinogenic effect of the Maillard reaction (Ledl and Schleicher, 1990; Mottram et al., 2002), the risks of injury or death from burning (Sanghavi et al., 2009), and the long-term health risks of smoke inhalation (Bruce et al., 2000; Smith et al., 2000).

The potentially most significant cost to fire and the one we will consider in this paper is the cost of gathering fuel. Even among present-day groups, who are all obligate fire users, there is considerable effort spent to maximize the returns from fuel collection. In Nepalese areas affected by deforestation, individuals both spend more time collecting fuel (up to an hour more per day) and use less fuel than in more wooded areas (Kumar and Hotchkiss, 1988). Kenyan agri-pastoralists prepare more quickly-

170 cooked foods in times of fuel scarcity (van Wijngaarden, 1984). Furthermore, these agri-pastoralists recognize the costs of carrying wood, and leave cut green wood to dry in public areas, thus potentially risking its loss, rather than carrying the heavy fresh wood back to the farm to cure (van Wijngaarden, 1984). Farmers in Iran are willing to lend their neighbors a glass of milk, but demand payment for dung cakes (the predominant fuel in this region) (Kramer, 1982). As mentioned previously, Arctic groups

175 have developed alternate means of preparing and preserving food, to avoid spending fuel on cooking these resources (Speth, 2017).

Archaeological evidence suggests that the costs of fuel have influenced human behavior for at least 10ka, and likely much longer. Bronze Age inhabitants of the Levant depleted their local wood resources due to increased smelting activities, and therefore shifted to using more tin in their bronze

180 because of its significantly lower melting temperature, which reduced their overall fuel needs (Kaufman, 2013; Kaufman and Scott, 2014). Archaic period inhabitants of southwest Texas and Coahuila Mexico relied on extremely refractive starchy plant resources that required lengthy roasting in a earth oven. To prepare the daily rations for 4-5 individuals, $250 \mathrm{~kg}$ of wood was needed (Dering, 1999). This quickly depleted local fuel sources and indicated that fuel and food scarcity, not water

185 availability, led to increasing mobility among these foragers. Due to local environmental features, Gravettian hunter-gatherers in the Pavlov Hills region of the Czech Republic likely quickly eliminated the naturally-occurring deadwood, and it may have taken several generations (40-120 years) for the deadwood to regenerate (Pryor et al., 2016). The authors proposed that these Gravettian people used intentional management strategies, such as geographic mobility and the deliberate killing of trees in 190 advance, in order to provide enough fuel for their planned visits to the sites.

The strategies used by recent historical groups and the archaeological evidence indicate that modern, obligate fire-users have a suite of behavioral adaptations for dealing with decreased fuel availability, or in other words, the costs of fuel. This cost clearly varies by environment and the availability of fuel, particularly standing dead wood. We suggest that for groups less dependent on fire

195 than modern humans, other adaptive strategies may have been used including the choice to build a fire only when fuel was abundant.

\subsection{Advantages of employing an economic approach:}

By conceptualizing fire as a tool to be used when needed rather than as a necessary part of a

200 hominin adaptation, we can use the methodologies derived from behavioral ecology to explore how and when such a tool might have been adopted, used and maintained (e.g., Bettinger et al., 2006; Ugan et al., 2003). By framing fire use in economic terms, we can create simple models that predict when fire should be used. As long as cumulative costs of fire outweigh the benefits, there should be no drive to adopt or use fire. 
While previous work has considered some of the costs associated with fire, including both time (Dunbar and Gowlett, 2014) and resources (Kaufman and Scott, 2014; Pryor et al., 2016), the actual energetic costs of creating a fire have never been quantified. These must be measured in order to have a meaningful comparison to the benefits of fire. We focus in this project on the costs of fuel collection compared to the benefits of cooked food, since both of these measures are comparable in terms of

210 calories. There are other possible comparisons, such as the increase in hunting efficiency measured as extra calories acquired when using heat-treated stones or composite tools, or the time savings from doing sedentary or maintenance tasks by fire-light. However, these are more challenging to measure, and based on previous research, they are likely to be smaller values than the major cost of fuel gathering and benefit of cooked foods.

\section{An example approach: costs of fuel gathering versus the caloric benefit of cooked foods}

In an attempt to demonstrate both the benefits and challenges of such an economic approach, we provide some calculations for the energetic costs of collecting fuel and compare these against the potential energy gained from consuming food cooked using that gathered fuel. These are rough

220 estimates and some of the problems with estimating caloric costs are highlighted by such an approach; nevertheless, the values we provide are the first attempt to actually measure the costs of fire and show that in some environments these costs are not outweighed by the energetic benefits of cooked foods.

We measured heart rate and distance traveled during bouts of fuel collection in three habitats with different levels of tree cover. We calculated the energetic costs (in $\mathrm{kJ} / \mathrm{min}$ ) based on measured

225 heart rates, and compared the costs of various fuel-collecting and related activities to the assumed energetic benefits derived from cooked food.

We recruited three volunteers, two men and a woman between the ages of 29 and 40, all of whom regularly exercised. This project was the pilot study for a larger project studying fuel gathering and food choices among foragers, which was approved by the Ethic Commission of the Medical

230 Faculty of Leipzig University, Permit number 196-16/ek. The volunteers were informed about the goals of the project and the potential risks and gave verbal consent to the project. They were equipped with an Adidas SmartRun wrist-worn heart rate monitor and GPS system. On three days over the course of a week, the volunteers hiked to specific areas within the Massif Central area of France that had been identified by satellite imagery to contain three different amounts of tree cover (Table 1, Figs 1 and 2).

235 This region of France was specifically chosen because it contained a variety of habitats, including regions above the tree line, which would have been similar to the areas inhabited by early pre-modern Europeans during both warm (forested) and cold (above the tree-line) time periods.

Table 1: Areas in the Massif Central region of France in which wood was collected.

\begin{tabular}{|c|c|c|c|c|}
\hline site name & lat., long. & habitat type & dominant tree taxa & activities measured \\
\hline $\begin{array}{l}\text { Puy de la } \\
\text { Vache }\end{array}$ & $\begin{array}{l}45.703 \\
2.957\end{array}$ & meadow & $\begin{array}{l}\text { Pinus sylvestris, Abies alba or } \\
\text { Picea abies (field ID unclear) }\end{array}$ & $\begin{array}{l}\text { hike in (no load), collect } \\
\text { fuel, hike out (no load) }\end{array}$ \\
\hline $\begin{array}{l}\text { Col du } \\
\text { Beal }\end{array}$ & $\begin{array}{l}45.686 \\
3.778\end{array}$ & field & Pinus sylvestris, Sorbus spp. & $\begin{array}{l}\text { hike in (no load), collect } \\
\text { fuel, hike out (with load), } \\
\text { burn fuel }\end{array}$ \\
\hline Parcourse & $\begin{array}{l}45.712 \\
2.971\end{array}$ & forest & $\begin{array}{l}\text { Fagus sylvestris, Pinus sylvestris, } \\
\text { Picea abies }\end{array}$ & $\begin{array}{l}\text { hike in (no load), collect } \\
\text { fuel, hike out (with load), } \\
\text { burn fuel }\end{array}$ \\
\hline
\end{tabular}




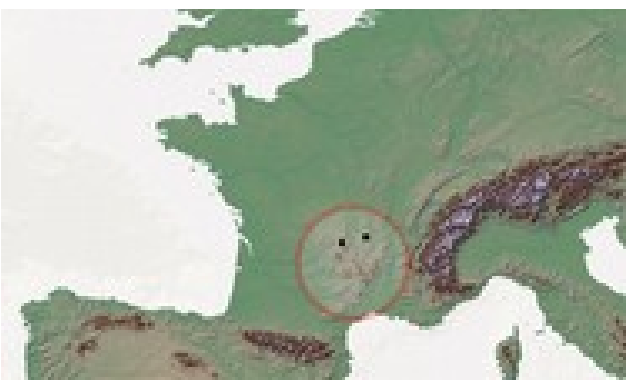

Fig 1: Map of south central France with the collection areas indicated. The point on the right is Col du Beal (field). The other dot represents Puy de la Vache (meadow) and Parcourse (forest), which are too close to each other to be separated at this scale.

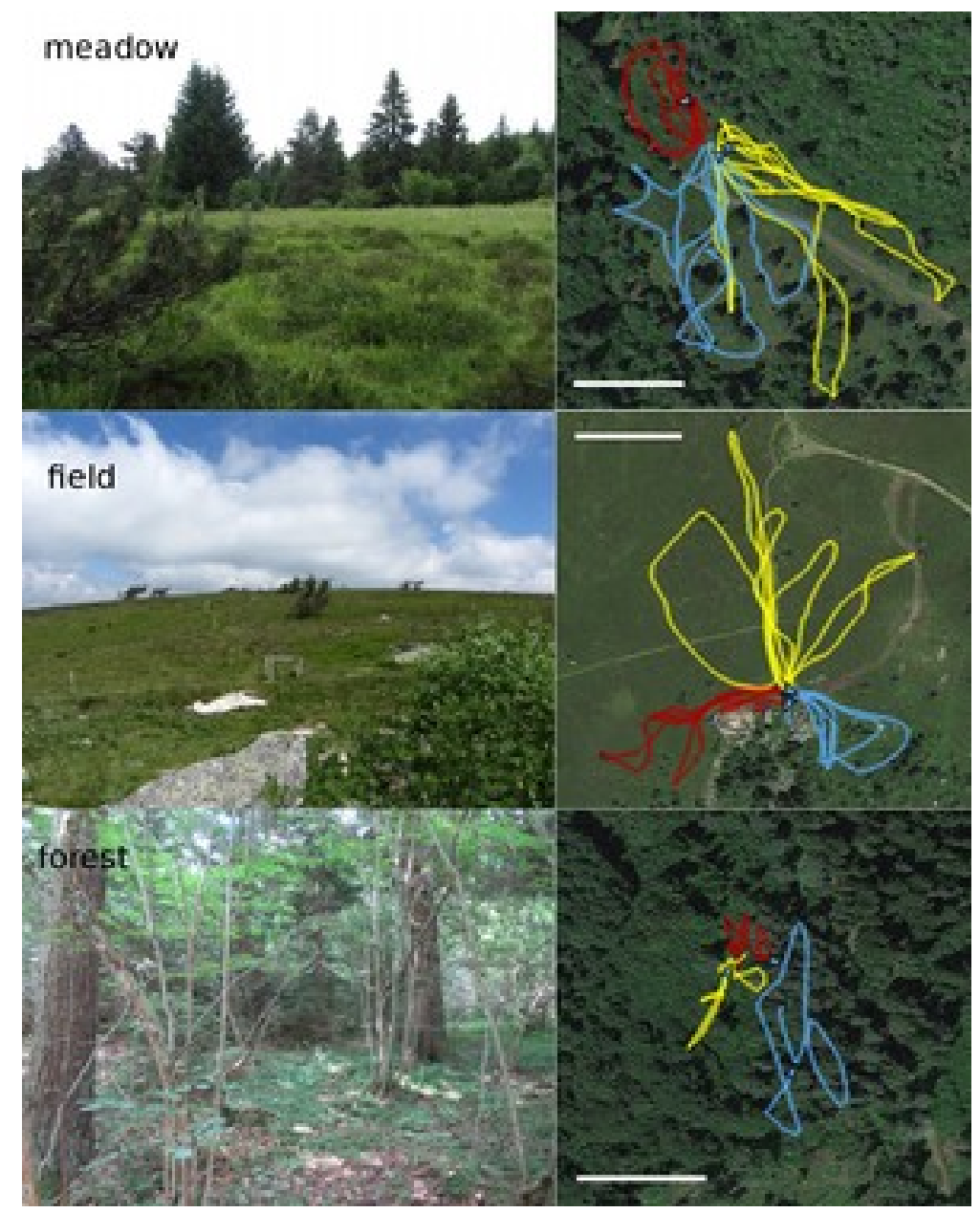

245 Fig 2: Pictures of the three collection areas and a satellite view of the paths taken by the three volunteers. Each color represents the path of an individual volunteer. The scale bar in each satellite image is 50m long. Top row: Puy de la Vache (meadow). Middle row: Col du Beal (field). Bottom row: Parcourse (forest).

250 The volunteers hiked at a comfortable pace from the trail head to the collecting area, where a central collection point was established. They were then instructed to spend 30 minutes collecting fuel, 
focusing on dry dead wood. The volunteers brought the collected wood back to the collection point once the load was too large or cumbersome, and then returned to collecting until the 30 minutes had passed (Fig 2). The total amount of fuel collected per person was weighed. From each volunteer's pile, two to three logs were chosen, and the moisture content measured in the field using a PCE-HGP wood moisture meter. Small sections were then cut from these pieces of wood, weighed, and brought back to the lab for a different measure of moisture content. The samples were kiln dried at $103^{\circ} \mathrm{C}$ until they lost no more weight. The moisture content was then assessed by subtracting the dry weight from the wet, dividing this difference by the dry weight, and multiplying by 100 . These moisture content

260 measurements provided one means of assessing the burn quality of the wood.

On the first day, the volunteers hiked out from the collection area to the car unencumbered. On the latter two collection days, the volunteers were instructed to pick up as large a load of wood from their pile as possible, and carry it back out from the collection point to the car. The carried load was then weighed, and one volunteer's pile was loaded into the car to take it to the place where burning was 265 allowed.

At the burning area, the single arm-load of fuel was broken by hand into shorter segments suitable for placement in a fire pit equipped with temperature sensors (Fig 3). One sensor was placed at the base of the fire, and the other held at $10 \mathrm{~cm}$ above the base. The fire was fed on a regular basis to keep up active flames. While a flaming fire is not ideal for cooking all foods, by keeping up active

270 flames we were able to standardize the rate at which the fire was fed. The rate of feeding was limited by the restricted size of the fire pit (c. 30 by $50 \mathrm{~cm}$ ). The fire was allowed to burn until all of the fuel was consumed and the flames could no longer be maintained, which took about 3.5 hours on both days. The volunteers continued to monitor their heart rate and position until all the fuel was burned.

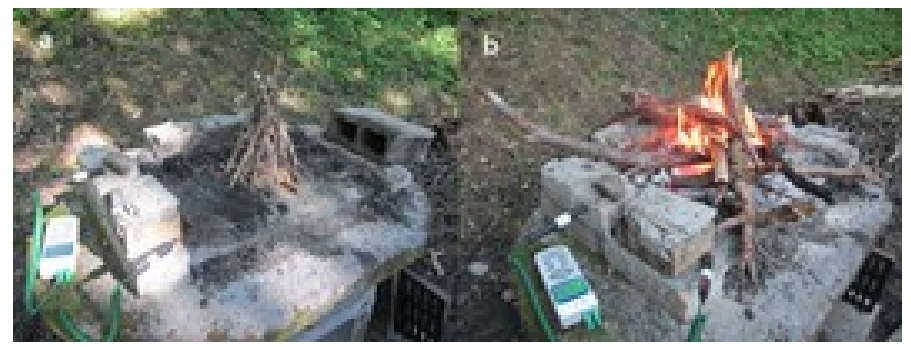

275 Fig 3: Fire pit set up. a) before lighting the fire. b) during the burning.

Finally, the volunteers also calculated a 'baseline' heart rate, in which they sat quietly indoors in the late morning (the same time of day as the fuel had been collected) for 30 minutes. In total, we collected heart rate and GPS data for hiking into the site on three days, collecting fuel on three days,

280 hiking out unencumbered on one day, carrying wood out on two days, and burning wood on two days, plus a final 'baseline' (Table 1).

Using a formula from Keytel and colleagues (2005) that allows us to estimate kilojoules (kJ) burned based on heart rate, accounting for age, sex and weight, we converted all of the heart rate data to $\mathrm{kJ}$ per minute. For men, the formula is: $-55.0969+0.6309 \times$ heart rate $+0.1988 \times$ weight $+0.2017 \times$

285 age. For women, the formula is: $-20.4022+0.4472 \times$ heart rate $+0.1263 \times$ weight $+0.074 \times$ age. This formula was designed to work with individuals performing moderate exercise, which we feel justified for the fuel collection and hiking data, but which may overestimate the kJ spent during the 'baseline' measurements and during the fuel burning.

\section{3. Results}


The raw heart rate and calculated kJ values are presented for each individual and activity in Fig 4, and the summary data are combined in Supplementary Tables 1 - 3.
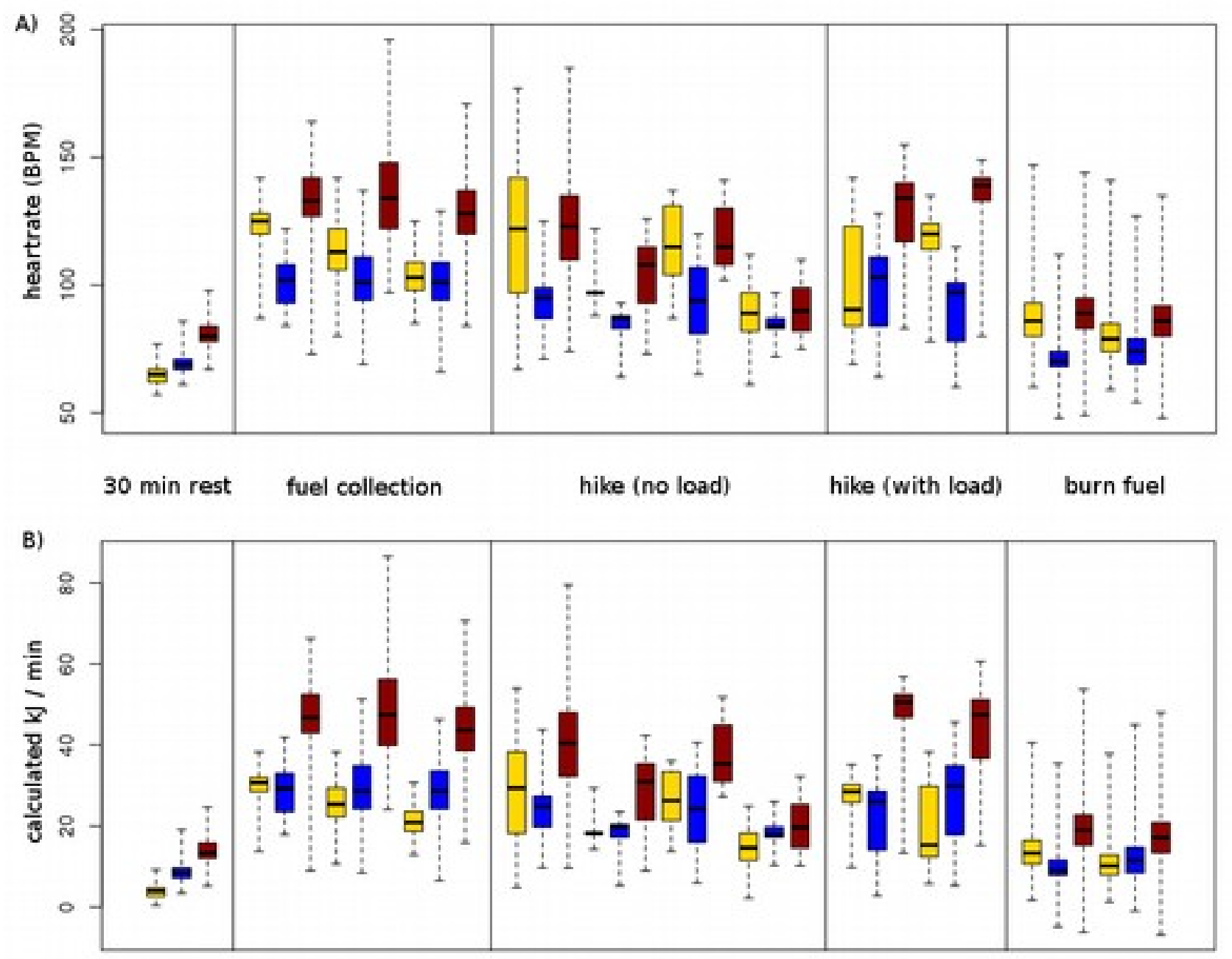

Fig 4: Energy spent on the various activities associated with fuel collection and fire burning. Top: measured heart rate values for each volunteer. Bottom: calculated $\mathrm{kJ} / \mathrm{min}$. Each volunteer is represented by a different color, and the labels apply to both graphs. Each set of three bars (yellow, blue, red) represents an individual activity. The fuel collection is ordered meadow, forest, field. The hike (no load) is ordered hike in meadow, hike out meadow, hike in field, hike in forest. The hike (with load) is ordered hike out field, hike out forest. The burn fuel is ordered burn fuel field, burn fuel forest.

300 The central bar is the median value and the box represents the first and last quartile, while the whiskers encompass the entire range.

\subsection{Fuel collection is more costly than hiking}

To compare activities among individuals, we calculated MET ("metabolic equivalent of task")

305 values from our $\mathrm{kJ} / \mathrm{min}$ estimates. MET values are used as a way of comparing among activities and for providing an estimate of energy consumption for tasks where direct oxygen consumption 
measurements are not possible. According to Ainsworth (2011), MET values are calculated as multiples of resting metabolic rate (RMR), so that each exercise is given a number roughly between 1 and 9, where 1 is identical to the resting rate and 9 indicates vigorous exercise. We converted our $\mathrm{kJ} / \mathrm{min}$ values to $\mathrm{kcal} / \mathrm{hour}$ for each exercise and for the resting period. We then divided the $\mathrm{kcal} / \mathrm{hour}$ for activities by the kcal/hour during the baseline rest, and the result was the MET value. We did not measure exact resting rate, and our caloric consumption is based instead on heart rate data and the formula from Keytel (2005). These modifications may explain why our "MET" values for activities like hiking and carrying do not match those published (Ainsworth et al., 2011). The lack of true RMR

315 measurement may also explain the very high "MET" values for individual 1, since this person had a very low heart rate during the baseline period. Individual 1 was also the only female in the study. However, by standardizing all our activities by the baseline rate, we can more easily compare the activities among individuals.

The results in Table 2 indicate that fuel collection is more costly than hiking in the same 320 landscapes. These data also indicate that carrying the fuel for longer distances (i.e. out from the collecting area to the car) is also costly, but less so than collecting the fuel. This is likely because fuel collection involves many more body movements (e.g., bending down, balancing the load on one arm, walking in a wandering pattern around the landscape) than does walking with a single load of fuel (which was generally straight-line walking on a path).

Table 2: "Metabolic equivalent of task" (MET) values for various activities at each location per collector.

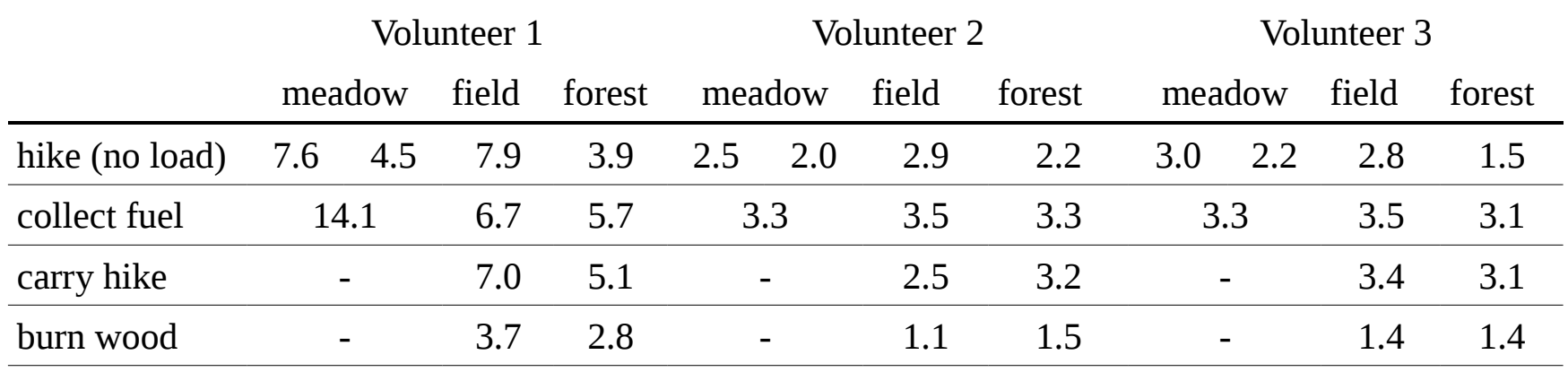

Note that our MET values were highest for collecting and carrying fuel, compared to hiking through the landscape.

\subsection{Open habitats were more costly}

To explore the variation among the three habitats we compared the total kJ burned during collection (Fig 5 and Table 3), the distance traveled during fuel collection (Table 4 and Fig 2), the total weight of fuel collected (Table 5), and also calculated the total number of kJ spent per $\mathrm{kg}$ of wood collected (Table 6). These data show clearly that the volunteers collected the most wood in the forested habitat and the least in the open habitat, and that they had to travel much further in the open habitat. While the total kJ burned did not appear to vary among habitats, the kJ spent per kg wood collected were much higher in the open habitats (meadow and field). These findings are perhaps unsurprising but represent the first data to directly and quantitatively compare fuel costs among different habitats. 


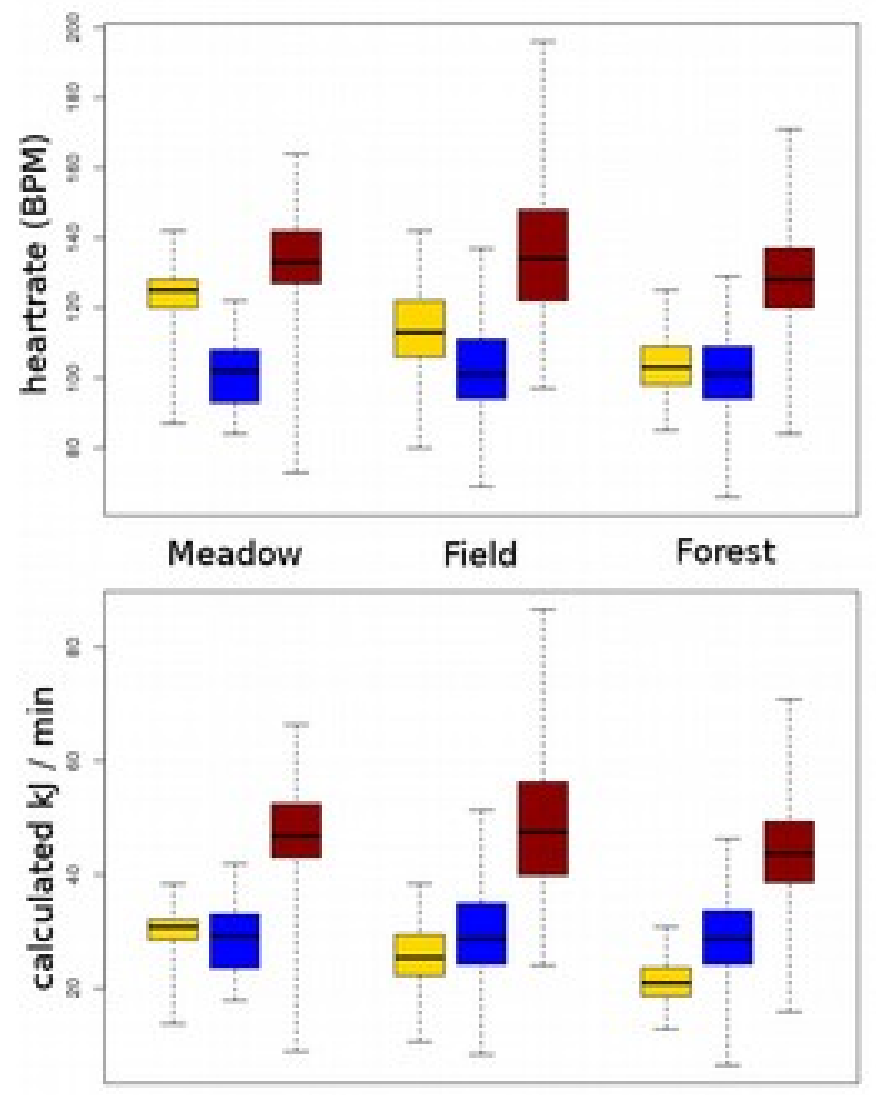

Fig 5: Energy spent collecting fuel in the three different habitats. Top: measured heart rate values for each volunteer; Bottom: calculated $\mathrm{kJ} / \mathrm{min}$. Each volunteer is represented in a different color and the 345 labels apply to both graphs. The central bar is the median value and the box represents the first and last quartile, while the whiskers encompass the entire range.

Table 3: Energy burned while collecting fuel in each habitat (in $\mathrm{kJ}$ ), summed for the entire 30 min collection period.

\begin{tabular}{lccc} 
& Volunteer 1 & Volunteer 2 & Volunteer 3 \\
\hline Meadow & 920.2 & 917.4 & 1433.3 \\
\hline Field & 717.2 & 910.5 & 1513.4 \\
\hline Forest & 651.4 & 915 & 1310.3
\end{tabular}

350 Values are generally highest in the field and meadow, but vary among volunteers.

Table 4: Distance traveled during fuel collection (in $\mathbf{k m}$ ).

\begin{tabular}{lcccc} 
& Volunteer 1 & Volunteer 2 & Volunteer 3 & Sum \\
\hline Meadow & 1.1 & 0.85 & 0.5 & 2.45 \\
\hline Field & 1.02 & 0.65 & 0.38 & 2.05 \\
\hline Forest & 0.15 & 0.12 & 0.29 & 0.56 \\
\hline
\end{tabular}

The volunteers covered much less distance in the forest environment. 
355 Table 5: Weight of fuel collected during $\mathbf{3 0}$ minutes, and carried out from a site (in $\mathbf{~ k g}$ ). Volunteer 1

Volunteer 2

Volunteer 3

\begin{tabular}{lcccccc} 
& Collected & Carried & Collected & Carried & Collected & Carried \\
\hline Meadow & 34.3 & - & 21.3 & - & 30.3 & - \\
\hline Field & 27.3 & 11.7 & 11.5 & 11.5 & 27.2 & 12.6 \\
\hline Forest & 49.7 & 19 & 56.8 & 18.5 & 89.2 & 17.8 \\
\hline Voln
\end{tabular}

Volunteers were able to collect the greatest amount of wood in the forest.

Table 6: Efficiency of fuel collection, measured as $\mathrm{kJ}$ spent per $\mathrm{kg}$ of wood.

\begin{tabular}{lccc} 
& Volunteer 1 & Volunteer 2 & Volunteer 3 \\
\hline Meadow & 26.8 & 43.1 & 47.3 \\
\hline Field & 26.3 & 79.2 & 55.6 \\
\hline Forest & 13.1 & 16.1 & 14.7
\end{tabular}

Lower values indicate better efficiency, and fuel collecting in the forest was most efficient for all three volunteers.

The recovery of more fuel from the forest habitat may not be as great a caloric advantage if that wood is of lower quality, however. Wet wood is heavier than dry and it is a lower quality fuel, both of which make it an energetically more costly item. We had expected that the wood collected in the forest would have been wetter than that from the drier habitats, somewhat offsetting the energetic benefits of the abundance of the wood. In fact, the carried weight of the wood for all volunteers was higher in the forest for the same rough volume of wood (one arm-load)(Table 5). Furthermore, we noted that it was more difficult to keep the fire going using the wood from the forest, and that we had to tend the fire more often to keep an even flame. To our surprise, however, the moisture content of the wood, whether measured by moisture content analyzer in the field or by small wood sections dried in our lab, was always highest in the field and lowest in the meadow, with the forest having middle values (Fig 6), but an ANOVA indicated that the differences among these sites were not significant for either means of measurement. We could not directly compare the temperatures of the two fires because the data logger malfunctioned on the day the wood from the field was burned. 


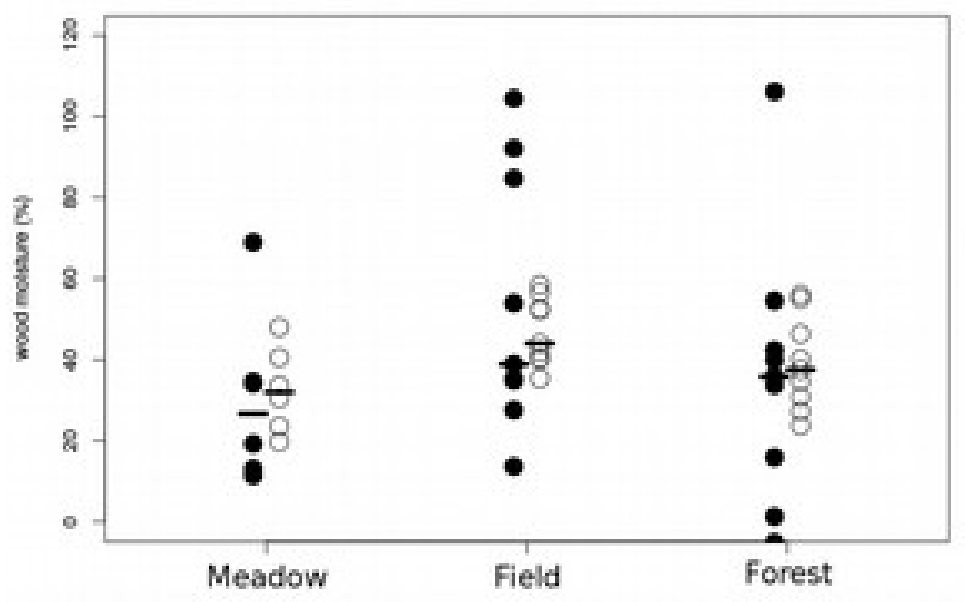

Fig 6 caption: Wood moisture values for each habitat. Closed circles indicate the moisture percentages measured with the probe while in the field. Open circles indicate the values for the same wood samples measured after oven drying. The bars indicate median values.

\subsection{The costs of fire can outweigh the benefits}

As a final calculation, we attempted to compare the energetic costs of fire as measured in this study to the energetic benefits that might be obtained from consuming food cooked on that fire. This proved surprisingly difficult, in large part because the energetic benefits of cooked food are poorly

385 quantified for humans. While previous work has clearly shown that mice fed cooked meat, tubers or nuts gain significantly more fat than those fed with iso-caloric raw meals (Carmody and Wrangham, 2009b; Groopman et al., 2015; though see Cornélio et al., 2016 for a contrasting view), there is no exact measurement for the caloric savings of consuming cooked foods for humans. We therefore attempted three different kinds of calculations; 1) using the USDA (US Department of Agriculture)

390 values for kilojoules present in raw and cooked foods (which reflects mostly the amount of water lost or gained in cooked food and the subsequent concentration or dispersal of nutrients, rather than differences in the actual costs of digestion), 2) using the energetic costs for digestion of raw and cooked beef by Burmese pythons (Boback et al., 2007), and 3) using average costs of digestion for humans and mammals on 'normal' diets that included predominantly cooked food for the former and raw food for

395 the latter. We calculated these values for several different food types, including both game meat (rabbit, caribou and white-tail deer); and root vegetables (carrot, salsify, burdock root, arrowhead, tiger nut) (Table 7). None of these taxa are entirely like those available to pre-modern humans because all of them are under at least some level of human control and have been spread outside of their original habitats and selected for particular traits. Some have been more highly altered compared to their wild 400 relatives (carrot, rabbit), while others remain more similar to the wild state (deer, salsify, arrowhead, tiger nut, burdock root). We chose these taxa to provide a range of potentially energy-rich foods that would have been available in northern-latitude habitats like those in which we collected fuel. 
405 Table 7: Energy available in various foods, both raw and cooked, in $\mathrm{kJ}$ per $100 \mathrm{~g}$

\begin{tabular}{ccccc} 
common name & species & $\begin{array}{c}\text { USDA accession } \\
\text { number }\end{array}$ & raw & cooked \\
\hline Deer & Odocoileus virginianus & 17164 \& 17165 & 502 & 661 \\
\hline Caribou & Rangifer tarandus & $17162 \& 17163$ & 531 & 699 \\
\hline Rabbit & Sylvilagus spp., Oryctolagus spp. & $17180 \& 17181$ & 477 & 724 \\
\hline Salsify & Tragopogon parrifolus & $11437 \& 11438$ & 343 & 284 \\
\hline Arrowhead & Sagittaria latifolia & $11005 \& 11006$ & 414 & 326 \\
\hline Burdock root & Arctium lappa & $11104 \& 11105$ & 302 & 369 \\
\hline Carrot & Daucus carota & $11124 \& 11125$ & 173 & 147 \\
\hline Tiger nut & Cyperus esculentus & NA & 1706 & NA \\
\hline
\end{tabular}

Energetic information for all food items except the tiger nut was acquired from the US Department of Agriculture Food Composition Database (US Department of Agriculture, Agricultural Research Service, Nutrient Data Laboratory, 2015). Information for the tiger nut was provided by the Spanish Food Composition database (Spanish Agency of Health and Nutrition, n.d.), which unfortunately does 410 not provide estimates for the energy of the cooked food.

For each food item, we then calculated the total weight of that food that would be needed for the benefits from eating that food cooked instead of raw to outweigh the costs of collecting fuel for that fire. To acquire costs of the fire, we calculated for each volunteer the total amount of energy spent

415 collecting and carrying the fuel, dividing these data by the final weight of fuel burned in the fire to get the energetic cost for only the amount of fuel used in the fire. We then added the energy spent while sitting around the fire. We did this separately for the data from the two days were we had burn data (from the forest and from the field). For example, in the forest Individual 1 spent $651.4 \mathrm{~kJ}$ to collect $49.7 \mathrm{~kg}$ of fuel. Only $19 \mathrm{~kg}$ of fuel was carried out of the forest and burned, so we multiplied 651.4 by

$42019 / 49.7$ to get the amount of kilojoules consumed while collecting the used amount of wood, which was $249 \mathrm{~kJ}$. To this latter value we added the $136.1 \mathrm{~kJ}$ individual 1 spent carrying the fuel out, and the $2361.1 \mathrm{~kJ}$ individual 1 spent curating the fire. The total is $2746 \mathrm{~kJ}$. Across all individuals these values range between $2983 \mathrm{~kJ}$ and $4673 \mathrm{~kJ}$ for the field, and $2746 \mathrm{~kJ}$ and $5043 \mathrm{~kJ}$ for the forest. This provided us with our minimum cost of $2746 \mathrm{~kJ}$ and maximum cost of $5043 \mathrm{~kJ}$.

425 For each food item we then calculated the benefits for cooking, using each of the three estimates for the energy freed by cooking (Table 8). These measurements do not account for the total energy available in the food, only the difference in energy between raw and cooked. For example, the first measure of benefits from cooking comes from the energetic values published by the USDA (US Department of Agriculture, Agricultural Research Service, Nutrient Data Laboratory, 2015). These

430 published values indicated that a baked burdock root provides $369 \mathrm{~kJ} / 100 \mathrm{~g}$ while a raw burdock root has $302 \mathrm{~kJ} / 100 \mathrm{~g}$. Cooking therefore provides a benefit of $67 \mathrm{~kJ}$ per $100 \mathrm{~g}$. In order to gain enough energy from this cooked food to offset the cost of collecting fuel and curating the fire (min $2746 \mathrm{~kJ}$, max $5043 \mathrm{~kJ}$ ), an individual would have to consume at least $4.1 \mathrm{~kg}$, and at most $7.5 \mathrm{~kg}$ of burdock roots, or roughly between 26 and 47 individual 160g roots (Table 8). It is unlikely that a forager could 435 collect (or would want to eat) 26 burdock roots. It is more plausible for a forager to have access to the $1.7 \mathrm{~kg}$ of deer meat needed to match the costs of fuel collection and cooking, but this amount is still well more than may be physically possible to consume in one sitting. We note also that the USDA 
database indicates energetic loss in some foods due to cooking (salsify, arrowhead and carrot), suggesting that no amount of cooking these foods could compensate for the energetic costs fire.

In a second means of calculating the benefits of cooked foods, we used the results from a study of digestion by Burmese pythons (Boback et al., 2007). Pythons spend 28 - 37 \% of the total energy in a meal of raw food just to digest it. In contrast, cooked foods require less energy to digest, and only 25 - $27 \%$ of the meal energy was spent on digestion. The authors of this study found no difference in caloric value of raw and cooked beef as measured by bomb calorimetry. Following this, then, we have

445 similarly calculated the digestive costs for our foods, assuming that both raw and cooked foods start with the same energetic value. Even using the lowest costs for cooked burdock roots (25\% digestive costs) and the highest costs for raw burdock roots (38\% digestive costs) we see only a $36 \mathrm{~kJ} / 100 \mathrm{~g}$ benefit to cooking. In this case, a forager would have to eat between 7.5 and $14 \mathrm{~kg}$ of cooked burdock roots to make up the energy lost in fuel gathering and fire curation. The same calculations give cooked 450 deer meat a $60 \mathrm{~kJ} / 100 \mathrm{~g}$ benefit, which would require a forager to consume between 4 and $8 \mathrm{~kg}$ of meat. We can also do the calculations for tiger nuts, which, due to their higher starting energy, would require only between 1.3 and $2.5 \mathrm{~kg}$ in order to match the cost of fire. Though this is a much lower weight than the other foods, given the small size of the average tiger nut (c. 1 x $1 \mathrm{~cm}$, Sánchez-Zapata et al., 2012), between 1900 and 3500 individual nuts would be needed to match the costs.

455 Of course, pythons are not the best reference animals for humans, being ectothermic and having very different digestive patterns. Studies of digestive costs in humans consuming controlled laboratory diets (that is, diets usually consisting of processed foods, often in liquid form) calculate the cost of digestion to average $7.2 \%$ of the consumed foods, while for most mammals on either a raw only or mixed raw and processed diet, the cost of digestion averages 9.9\% (Secor, 2009). We used the average

460 human value to represent the energetic cost of digesting cooked food, and the average animal value as the cost for digesting raw food. Using these values, a cooked burdock root provides a $8 \mathrm{~kJ} / 100 \mathrm{~g}$ benefit, while deer meat gives a $13 \mathrm{~kJ} / 100 \mathrm{~g}$ benefit. A forager would have to eat between 33 and 61 $\mathrm{kg}$ of burdock root and 20 to $37 \mathrm{~kg}$ of deer meat in order to match the costs of fuel gathering and fire curation.

465 The summary data for each food type and energetic benefit calculation is provided in table 8, and the detailed calculations are provided in supplementary tables 4-6. 
Table 8: Energetic benefits from cooking calculated three different ways, and the total weight of food needed to match the energetic costs of fuel collecting and fire curation.

\begin{tabular}{ccccccc} 
& $\begin{array}{c}\text { benefit } \\
\text { USDA } \\
(\mathrm{kJ} / 100 \mathrm{~g})\end{array}$ & $\begin{array}{l}\text { weight } \\
\text { needed to } \\
\text { match costs } \\
(\mathrm{kg})\end{array}$ & $\begin{array}{l}\text { benefit } \\
\text { python } \\
(\mathrm{kJ} / 100 \mathrm{~g})\end{array}$ & $\begin{array}{l}\text { weight } \\
\text { needed to } \\
\text { match costs } \\
(\mathrm{kg})\end{array}$ & $\begin{array}{l}\text { benefit } \\
\text { feeding tests } \\
(\mathrm{kJ} / 100 \mathrm{~g})\end{array}$ & $\begin{array}{l}\text { weight } \\
\text { needed to } \\
\text { match costs } \\
(\mathrm{kg})\end{array}$ \\
\hline Deer & 159 & $1.7-3.2$ & 60 & $4.6-8.4$ & 13 & $20.2-37.2$ \\
\hline Caribou & 168 & $1.6-3.0$ & 64 & $4.3-7.9$ & 14 & $19.1-35.1$ \\
\hline Rabbit & 247 & $1.1-2.0$ & 57 & $4.8-8.8$ & 13 & $21.3-39.1$ \\
\hline Salsify & -59 & - & 41 & $6.6-12.3$ & 9 & $29.6-54.5$ \\
\hline Arrowhead & -88 & - & 50 & $5.5-10.2$ & 11 & $24.6-45.1$ \\
\hline Burdock root & 67 & $4.1-7.5$ & 36 & $7.6-13.9$ & 8 & $33.7-61.8$ \\
\hline Carrot & -26 & - & 20 & $13.2-24.3$ & 4 & $58.8-108.0$ \\
\hline Tiger nut & na & na & 204 & $1.3-2.5$ & 46 & $6.0-10.9$
\end{tabular}

These calculations highlight the difficulty in understanding the energetic benefits of cooked food. In particular it would be helpful to have studies in humans, or at least in mammalian model organisms, that explicitly test the cost of digesting raw and cooked food, which also measure the intrinsic energetic value of these foods. We were unable to find any such studies. If taken at face value, our calculations further show that the benefits of cooking can vary considerably, depending on the kind of food consumed, and how it responds to cooking. It is generally assumed, too, that cooking increases the digestibility of foods, but most studies so far have focused only on domesticated foods. Preliminary work with wild plant foods has shown that cooking in some cases reduces the bioavailability of glucose (Schnorr et al., 2015), which is one of the major sources of energy in these plant foods. The cooking of these foods would decrease, rather than increase, their energetic value relative to raw foods. The benefits of fire and cooking will depend heavily on the types of food cooked on the fire.

\section{Discussion}

This preliminary study supports the view that an optimal forager must consider the costs of fire, and that these costs may have outweighed the benefits of cooking food, depending on the habitat and the food type. This paper is meant to reinforce the importance of using an economic view, and to emphasize that the costs of fire must be considered when exploring why fire was used. We caution that the numbers we provide for kilojoules spent during fuel collection should not be taken as exact values for living humans or extrapolated directly to earlier hominins. Several modifications to the method, such as using a mask-based oxygen monitoring system as in Prado-Nóvoa et al. (2017) rather than wrist-worn heart rate monitors, and working with groups who are experienced fuel collectors would greatly improve the accuracy and applicability of these numbers.

495 Future research should also consider the costs of other fuel types such as dung, peat, green wood or brushwood, and how the costs of fuel collecting might vary if collection is embedded in other subsistence activities. Often, individuals will stop for fuel on the way home from other tasks (Picornell 
Gelabert et al., 2011). While this might save time, it would not decrease the energetic costs for picking up and carrying the fuel, which were the two most expensive tasks in our experiment.

$500 \quad$ Furthermore, the kind of fire we used (a pit fire) likely burned faster than other more fuelefficient types of fires. Some studies have shown that regular fire users can be very efficient with their use of fuel. Among the Sherpa of Nepal, for example, most households use about 14kg of fuel per day (Stevens, 1990). This is rather less than the $19 \mathrm{~kg}$ of fuel that we burned over 3.5 hours. However, the process of cooking may require that certain temperatures be reached over large areas (especially when 505 cooking the amounts of food that we calculated to be needed to reach caloric balance), meaning that a small efficient fire may not be sufficient in all cases.

Our study explicitly did not use any kind of carrying technology to make the fuel collection easier. The limiting factor in the amount of fuel that was brought to the burning site was the size of the arm-load that the volunteers were able to carry away from the collection site. Far more fuel was

510 collected during the 30 minute collection period than was possible to transport over longer distances. Even simple technologies, such as a rope or hide sack, would have made a large difference in the amount of fuel carried out. This kind of technology would have been available quite early in hominin history, and would certainly lower the relative cost of fuel collection.

Despite these potential problems with this study, our data do provide a good starting point to

515 consider the costs of fuel collection, and bring attention to fuel collection strategies and technologies likely to decrease the cost of fire.

Collecting fuel has costs in every environment, but our data indicate that the degree of woody vegetation is a strong determinant of the energetic cost of fuel. Fire-using hominins may always have to make trade offs between open habitats where prey is easier to see, and closed habitats, where wood fuel

520 is abundant. It is perhaps unsurprising to often find hominin sites in areas of ecotones, where the advantages of all habitat types might be exploited.

The spreading out of the costs of fuel, either through time or across individuals, might make fire use more economically valuable. Food might be cooked and consumed later, spreading the cost of the fire out over several meals. This amortization of the costs of cooking would be more successful for

525 foods, like large game, that come in bigger packages. Many cuts of meat from the same animal could be cooked on the same fire, and then consumed over several days. The limitation for plant foods seems to be the sheer volume of plant material that would need to be harvested in order to offset the costs of fuel collection and fire curation. Sharing the costs of fire among a group might be another way in which hominins addressed the problem of fuel collection. Our data indicate that the costs of fire cannot

530 be met for an individual by any food type for any single meal. However, larger groups can share these costs more effectively, with either individual task specialization, or where individuals take turns accruing costs and then 'free-loading' on a fire built by others. This division of labor is seen among many modern human groups, with women and children disproportionately providing fuel, while men and adults are generally responsible for providing the food (Cain, 1977; Haile, 1989). However, it is

535 unclear the size of the group for which cost sharing would become effective, and this would also depend on the amount and types of food available.

Considering our results in the context of the archaeological record, we think it is possible that hominins were occasional or even habitual fire users quite early on. However, given the high and environmentally variable costs of fire, we think it is likely that hominins did not become obligate users 540 of fire until quite late, supporting the views espoused by Sandgathe (2017) and Chazan (2017). This interpretation will allow us to more critically examine the archaeological evidence. Provided that taphonomic processes have been assessed, if we really see evidence that hominin groups were not using fire in particular times and places, then it may be possible to conclude that the costs of fuel outweighed 
the benefits. This could be because the surrounding habitat was fuel depauperate, or that the daily tasks

545 carried out by that hominin group were not sufficiently enhanced by fire to make collecting the fuel worthwhile.

\section{Conclusion}

The consideration of fire as a tool, rather than as a biological trait, allows us to better

550 understand the archaeological and behavioral record. The use or creation of fire is not necessarily a complicated task that required an intuitive leap. Sometimes a tool is easy to make, but if the costs of making that tool are too high relative to the benefits, it will not be made. Our current physiological and cultural adaptation to fire in the present and recent past tells us nothing about its relevance in the deep past. These developments occurred only later, would not have been driving force in the first adoption of 555 fire.

The variability of fire evidence in the deep past is in part due to taphonomic processes affecting the archaeological record, but also because in certain times and places, hominins, who did not have our physiology or the same fundamental reliance on cooked foods, simply chose not to make fire.

\section{Acknowledgements}

AGH thanks R. McElreath, A. Sorensen, F. Reidsma, W. Roebroeks, A. Crittenden and S. Schnorr for helpful discussions in the preparation of this manuscript. This project was funded in part by the Max Planck Society and the European Research Council (ERC) under the European Union's Horizon 2020

565 research and innovation program under grant agreement number STG-677576 (“HARVEST”).

\section{Data Availability}

The raw data from the heart rate and GPS monitors is available on figshare under the collection "Raw data from "Towards an understanding of the costs of fire" at the following address:

10.6084/m9.figshare.c.4118195

\section{References Cited}

Ainsworth, B.E., Haskell, W.L., Herrmann, S.D., Meckes, N., Bassett Jr, D.R., Tudor-Locke, C., Greer, J.L., Vezina, J., Whitt-Glover, M.C., Leon, A.S., 2011. 2011 Compendium of Physical Activities: a second update of codes and MET values. Med. Sci. Sports Exerc. 43, 1575-1581. Alperson-Afil, N., 2017. Spatial Analysis of Fire: Archaeological Approach to Recognizing Early Fire. Curr. Anthropol. 58, S258-S266. https://doi.org/10.1086/692721

Barkai, R., Rosell, J., Blasco, R., Gopher, A., 2017. Fire for a Reason: Barbecue at Middle Pleistocene Qesem Cave, Israel. Curr. Anthropol. S000-S000. https://doi.org/10.1086/691211

Bettinger, R.L., Winterhalder, B., McElreath, R., 2006. A simple model of technological intensification. J. Archaeol. Sci. 33, 538-545. https://doi.org/10.1016/j.jas.2005.09.009

Boback, S.M., Cox, C.L., Ott, B.D., Carmody, R., Wrangham, R.W., Secor, S.M., 2007. Cooking and grinding reduces the cost of meat digestion. Comp. Biochem. Physiol. Part A 148, 651-656. 
Bruce, N., Perez-Padilla, R., Albalak, R., 2000. Indoor air pollution in developing countries: a major environmental and public health challenge. Bull. World Health Organ. 78, 1078-1092. https://doi.org/10.1590/S0042-96862000000900004

Cain, M.T., 1977. The Economic Activities of Children in a Village in Bangladesh. Popul. Dev. Rev. 3, 201-227. https://doi.org/10.2307/1971889

Carmody, R.N., Wrangham, R.W., 2009a. Cooking and the human commitment to a high-quality diet. Cold Spring Harb. Symp. Quant. Biol.

Carmody, R.N., Wrangham, R.W., 2009b. The energetic significance of cooking. J. Hum. Evol. 57, 379-391.

Chazan, M., 2017. Toward a Long Prehistory of Fire. Curr. Anthropol. 58, S351-S359. https://doi.org/10.1086/691988

Cornélio, A.M., de Bittencourt-Navarrete, R.E., de Bittencourt Brum, R., Queiroz, C.M., Costa, M.R., 2016. Human Brain Expansion during Evolution Is Independent of Fire Control and Cooking. Front. Neurosci. 10. https://doi.org/10.3389/fnins.2016.00167

Dering, P., 1999. Earth-Oven Plant Processing in Archaic Period Economies: An Example from a SemiArid Savannah in South-Central North America. Am. Antiq. 64, 659-674. https://doi.org/10.2307/2694211

Dibble, H.L., Abodolahzadeh, A., Aldeias, V., Goldberg, P., McPherron, S.P., Sandgathe, D.M., 2017. How Did Hominins Adapt to Ice Age Europe without Fire? Curr. Anthropol. S000-S000. https://doi.org/10.1086/692628

Domanski, M., Webb, J.A., 1992. Effect of heat treatment on siliceous rocks used in prehistoric lithic technology. J. Archaeol. Sci. 19, 601-614. https://doi.org/10.1016/0305-4403(92)90031-W

Dunbar, R.I., Gowlett, J.A., 2014. Fireside chat: the impact of fire on hominin socioecology. Lucy Lang. Benchmark Pap. 277-296.

Gao, X., Zhang, S., Zhang, Y., Chen, F., 2017. Evidence of Hominin Use and Maintenance of Fire at Zhoukoudian. Curr. Anthropol. 58, S267-S277. https://doi.org/10.1086/692501

Groopman, E.E., Carmody, R.N., Wrangham, R.W., 2015. Cooking increases net energy gain from a lipid-rich food. Am. J. Phys. Anthropol. 156, 11-18. https://doi.org/10.1002/ajpa.22622

Haile, F., 1989. Women Fuelwood Carriers and the Supply of Household Energy in Addis Ababa. Can. J. Afr. Stud. Rev. Can. Études Afr. 23, 442-451. https://doi.org/10.1080/00083968.1989.10804269

Harcourt-Smith, W.E.H., 2007. 5 The Origins of Bipedal Locomotion, in: Handbook of Paleoanthropology. Springer, Berlin, Heidelberg, pp. 1483-1518. https://doi.org/10.1007/978-3540-33761-4_48

Henry, A.G., 2017. Neanderthal Cooking and the Costs of Fire. Curr. Anthropol. 58, S329-S336. https://doi.org/10.1086/692095

Hlubik, S., Berna, F., Feibel, C., Braun, D., Harris, J.W.K., 2017. Researching the Nature of Fire at 1.5 Mya on the Site of FxJj20 AB, Koobi Fora, Kenya, Using High-Resolution Spatial Analysis and FTIR Spectrometry. Curr. Anthropol. 58, S243-S257. https://doi.org/10.1086/692530

Kaufman, B., 2013. Copper Alloys from the 'Enot Shuni Cemetery and the Origins of Bronze Metallurgy in the EB IV - MB II Levant. Archaeometry 55, 663-690. https://doi.org/10.1111/j.1475-4754.2012.00699.x

Kaufman, B., Scott, D.A., 2014. Fuel Efficiency of Ancient Copper Alloys: Theoretical Melting Thermodynamics of Copper, Tin and Arsenical Copper and Timber Conservation in the Bronze Age Levant. Archaeometry 57, 1009-1024. https://doi.org/10.1111/arcm.12127 
Keytel, L.R., Goedecke, J.H., Noakes, T.D., Hiiloskorpi, H., Laukkanen, R., Merwe, L. van der, Lambert, E.V., 2005. Prediction of energy expenditure from heart rate monitoring during submaximal exercise. J. Sports Sci. 23, 289-297.

https://doi.org/10.1080/02640410470001730089

Kramer, C., 1982. Village ethnoarchaeology: rural Iran in archaeological perspective. Academic Press New York.

Kumar, S.K., Hotchkiss, D., 1988. Consequences of Deforestation for Women's Time Allocation, Agricultural Production, and Nutrition in Hill Areas of Nepal. Intl Food Policy Res Inst.

Ledl, F., Schleicher, E., 1990. New Aspects of the Maillard Reaction in Foods and in the Human Body. Angew. Chem. Int. Ed. Engl. 29, 565-594. https://doi.org/10.1002/anie.199005653

Marlowe, F.W., 2010. The Hadza: Hunter-gatherers of Tanzania. University of California Press, Berkeley, CA.

Mazza, P.P.A., Martini, F., Sala, B., Magi, M., Colombini, M.P., Giachi, G., Landucci, F., Lemorini, C., Modugno, F., Ribechini, E., 2006. A new Palaeolithic discovery: tar-hafted stone tools in a European Mid-Pleistocene bone-bearing bed. J. Archaeol. Sci. 33, 1310-1318. https://doi.org/10.1016/j.jas.2006.01.006

Mottram, D.S., Wedzicha, B.L., Dodson, A.T., 2002. Food chemistry: Acrylamide is formed in the Maillard reaction. Nature 419, 448-449. https://doi.org/10.1038/419448a

Ofek, H., 2001. Second Nature: Economic Origins of Human Evolution. Cambridge University Press.

Picornell Gelabert, L., Asouti, E., Martí, E.A., 2011. The ethnoarchaeology of firewood management in the Fang villages of Equatorial Guinea, central Africa: Implications for the interpretation of wood fuel remains from archaeological sites. J. Anthropol. Archaeol. 30, 375-384. https://doi.org/10.1016/j.jaa.2011.05.002

Prado-Nóvoa, O., Mateos, A., Zorrilla-Revilla, G., Vidal-Cordasco, M., Rodríguez, J., 2017. Efficiency of gathering and its archaeological implications for an European Early Palaeolithic population. J. Anthropol. Archaeol. 45, 131-141. https://doi.org/10.1016/j.jaa.2016.12.002

Pruetz, J.D., Herzog, N.M., 2017. Savanna Chimpanzees at Fongoli, Senegal, Navigate a Fire Landscape. Curr. Anthropol. 58, S337-S350. https://doi.org/10.1086/692112

Pryor, A.J.E., Pullen, A., Beresford-Jones, D.G., Svoboda, J.A., Gamble, C.S., 2016. Reflections on Gravettian firewood procurement near the Pavlov Hills, Czech Republic. J. Anthropol. Archaeol. 43, 1-12. https://doi.org/10.1016/j.jaa.2016.05.003

Roebroeks, W., Villa, P., 2011. On the earliest evidence for habitual use of fire in Europe. Proc. Natl. Acad. Sci. 108, 5209-5214. https://doi.org/10.1073/pnas.1018116108

Sánchez-Zapata, E., Fernández-López, J., Angel Pérez-Alvarez, J., 2012. Tiger Nut (Cyperus esculentus) Commercialization: Health Aspects, Composition, Properties, and Food Applications. Compr. Rev. Food Sci. Food Saf. 11, 366-377. https://doi.org/10.1111/j.15414337.2012.00190.x

Sandgathe, D.M., 2017. Identifying and Describing Pattern and Process in the Evolution of Hominin Use of Fire. Curr. Anthropol. 58, S360-S370. https://doi.org/10.1086/691459

Sandgathe, D.M., Dibble, H.L., Goldberg, P., McPherron, S.P., Turq, A., Niven, L., Hodgkins, J., 2011. On the role of fire in Neandertal adaptations in western Europe: evidence from Pech de l'Azé IV and Roc de Marsal, France. PaleoAnthropology 2011, 216-242.

Sanghavi, P., Bhalla, K., Das, V., 2009. Fire-related deaths in India in 2001: a retrospective analysis of data. The Lancet 373, 1282-1288. https://doi.org/10.1016/S0140-6736(09)60235-X 
Schnorr, S.L., Crittenden, A.N., Venema, K., Marlowe, F.W., Henry, A.G., 2015. Assessing digestibility of Hadza tubers using a dynamic in-vitro model. Am. J. Phys. Anthropol. n/a-n/a. https://doi.org/10.1002/ajpa.22805

Scholander, P.F., Hammel, H.T., Hart, J.S., LeMessurier, D.H., Steen, J., 1958. Cold Adaptation in Australian Aborigines. J. Appl. Physiol. 13, 211-218.

Secor, S.M., 2009. Specific dynamic action: a review of the postprandial metabolic response. J. Comp. Physiol. B 179, 1-56. https://doi.org/10.1007/s00360-008-0283-7

Smith, K.R., Samet, J.M., Romieu, I., Bruce, N., 2000. Indoor air pollution in developing countries and acute lower respiratory infections in children. Thorax 55, 518-532. https://doi.org/10.1136/thorax.55.6.518

Spanish Agency of Health and Nutrition, n.d. BEDCA: Base de Datos Española de Composición de Alimentos [WWW Document]. URL http://www.bedca.net/bdpub/index.php (accessed 1.12.18).

Speth, J.D., 2017. Putrid Meat and Fish in the Eurasian Middle and Upper Paleolithic: Are We Missing a Key Part of Neanderthal and Modern Human Diet? PaleoAnthropology 2017, 44-72.

Stevens, S.F., 1990. Sherpa Settlement And Subsistance: Cultural Ecology And History In Highland Nepal. University Microfilms International, Ann Arbor, Mich.

Tanno, T., 1981. Plant utilization of the Mbuti Pygmies-with special reference to their material culture and use of wild vegetable foods. Afr. Study Monogr. 1, 1-53.

Twomey, T., 2013. How domesticating fire facilitated the evolution of human cooperation. Biol. Philos. 29, 89-99. https://doi.org/10.1007/s10539-013-9402-2

Ugan, A., Bright, J., Rogers, A., 2003. When is technology worth the trouble? J. Archaeol. Sci. 30, 1315-1329. https://doi.org/10.1016/S0305-4403(03)00022-0

US Department of Agriculture, Agricultural Research Service, Nutrient Data Laboratory, 2015. USDA National Nutrient Database for Standard Reference, Release 28.

van Wijngaarden, J., 1984. The Patterns of Fuel Gathering and Use in a Rural Area of Machakos District, Kenya. Wageningen Agricultural University, Wageningen, The Netherlands.

White, R., Mensan, R., Clark, A.E., Tartar, E., Marquer, L., Bourrillon, R., Goldberg, P., Chiotti, L., Cretin, C., Rendu, W., Pike-Tay, A., Ranlett, S., 2017. Technologies for the Control of Heat and Light in the Vézère Valley Aurignacian. Curr. Anthropol. 58, S288-S302. https://doi.org/10.1086/692708

Wiessner, P.W., 2014. Embers of society: Firelight talk among the Ju/'hoansi Bushmen. Proc. Natl. Acad. Sci. 111, 14027-14035. https://doi.org/10.1073/pnas.1404212111

Wrangham, R., Carmody, R., 2010. Human adaptation to the control of fire. Evol. Anthropol. Issues News Rev. 19, 187-199. https://doi.org/10.1002/evan.20275

Wrangham, R.W., Conklin-Brittain, N.L., 2003. Cooking as a biological trait. Comp. Biochem. Physiol. Part A 136, 35-46.

Wrangham, R.W., Jones, J.H., Laden, G., Pilbeam, D.R., Conklin-Brittain, N.L., 1999. The raw and the stolen: Cooking and the ecology of human origins. Curr Anthr. 40, 567-594.

Zink, K.D., Lieberman, D.E., Lucas, P.W., 2014. Food material properties and early hominin processing techniques. J. Hum. Evol., The Role of Freshwater and Marine Resources in the Evolution of the Human Diet, Brain and Behavior 77, 155-166.

https://doi.org/10.1016/j.jhevol.2014.06.012 
Supplemental Table 1: Data collected from Volunteer 1 (female, 35yo)

\begin{tabular}{|c|c|c|c|c|c|c|c|c|c|c|c|c|c|}
\hline Action & $\begin{array}{c}\text { distance } \\
(\mathrm{km})\end{array}$ & $\begin{array}{l}\text { time elapsed } \\
\text { (h:m:s) }\end{array}$ & $\begin{array}{l}\text { elevation } \\
\text { gain (m) }\end{array}$ & $\max \mathrm{hr}$ & $\min \mathrm{hr}$ & median hr & $\begin{array}{c}\max \\
\mathrm{kJ} / \mathrm{min}\end{array}$ & $\begin{array}{c}\min \\
\mathrm{kJ} / \mathrm{min}\end{array}$ & $\begin{array}{l}\text { median } \\
\mathrm{kJ} / \mathrm{min}\end{array}$ & total $\mathrm{kJ}$ & $\begin{array}{l}\text { total } \\
\text { kcal }\end{array}$ & $\begin{array}{l}\text { kcal/ } \\
\text { hour }\end{array}$ & $\begin{array}{l}\text { "MET" } \\
\text { value }\end{array}$ \\
\hline Hike in Meadow & 2.89 & $00: 56: 10$ & 182 & 177 & 67 & 122 & 54 & 4.8 & 29.4 & 1626.4 & 388.7 & 416 & 7.6 \\
\hline Collect fuel Meadow & 1.1 & $00: 30: 42$ & 27 & 142 & 87 & 125 & 38 & 13.7 & 30.7 & 920.2 & 219.8 & 777 & 14.1 \\
\hline Hike out Meadow & 0.58 & 00:12:19 & 33 & 122 & 88 & 97 & 29.4 & 14.2 & 18.2 & 207.4 & 49.4 & 247 & 4.5 \\
\hline Hike in Field & 0.26 & 00:06:43 & 23 & 137 & 87 & 115 & 36.1 & 13.8 & 26.3 & 181.1 & 43.3 & 433 & 7.9 \\
\hline Collect fuel Field & 1.02 & $00: 27: 57$ & 39 & 142 & 80 & 113 & 38.6 & 10.6 & 25.4 & 717.2 & 171.3 & 367 & 6.7 \\
\hline Carry out Field & 0.4 & 00:07:07 & 0 & 135 & 78 & 120 & 35.2 & 9.7 & 28.5 & 188.1 & 44.9 & 387 & 7.0 \\
\hline Burn wood Field & 1.49 & 03:16:27 & 54 & 147 & 60 & 86 & 40.6 & 1.7 & 13.3 & 2746.5 & 655.9 & 201 & 3.7 \\
\hline Hike in Forest & 0.44 & $00: 07: 25$ & 5 & 112 & 61 & 89 & 24.9 & 2.1 & 14.7 & 108.4 & 24.9 & 213 & 3.9 \\
\hline Collect fuel Forest & 0.15 & 00:30:41 & 4 & 125 & 85 & 103 & 30.8 & 12.9 & 20.9 & 651.4 & 155.6 & 311 & 5.7 \\
\hline Carry out Forest & 0.48 & 00:06:55 & 9 & 142 & 69 & 90.5 & 38.4 & 5.7 & 15.3 & 136.1 & 32.5 & 279 & 5.1 \\
\hline Burn wood Forest & 1.29 & $03: 37: 27$ & 59 & 141 & 59 & 79 & 37.9 & 1.2 & 10.2 & 2361.1 & 563.9 & 156 & 2.8 \\
\hline 30 min rest & 0 & 00:29:29 & 0 & 77 & 61 & 65 & 9.3 & 0.35 & 3.9 & 115.2 & 27.5 & 55 & 1 \\
\hline
\end{tabular}


Supplemental Table 2: Data collected from Volunteer 2 (male, 40yo)

\begin{tabular}{|c|c|c|c|c|c|c|c|c|c|c|c|c|c|}
\hline Action & $\begin{array}{c}\text { distance } \\
(\mathrm{km})\end{array}$ & $\begin{array}{l}\text { time elapsed } \\
\text { (h:m:s) }\end{array}$ & $\begin{array}{l}\text { elevation } \\
\text { gain (m) }\end{array}$ & $\max \mathrm{hr}$ & $\min \mathrm{hr}$ & median hr & $\begin{array}{c}\max \\
\mathrm{kJ} / \mathrm{min} \\
\end{array}$ & $\begin{array}{c}\min \\
\mathrm{kJ} / \mathrm{min}\end{array}$ & $\begin{array}{l}\text { median } \\
\mathrm{kJ} / \mathrm{min} \\
\end{array}$ & total kJ & $\begin{array}{l}\text { total } \\
\text { kcal } \\
\end{array}$ & $\begin{array}{l}\text { kcal/ } \\
\text { hour }\end{array}$ & $\begin{array}{l}\text { "MET" } \\
\text { value } \\
\end{array}$ \\
\hline Hike in Meadow & 2.95 & $00: 55: 43$ & 185 & 125 & 71 & 95 & 43.8 & 9.7 & 24.8 & 1210.2 & 289.5 & 316 & 2.5 \\
\hline Collect fuel Meadow & 0.85 & 00:31:55 & 17 & 122 & 84 & 102 & 41.9 & 17.9 & 29.2 & 917.4 & 219.1 & 411 & 3.3 \\
\hline Hike out Meadow & 0.99 & $00: 12: 40$ & 21 & 93 & 64 & 87 & 23.6 & 5.3 & 19.8 & 227.6 & 54.4 & 251 & 2.0 \\
\hline Hike in Field & 0.26 & 00:06:18 & 20 & 120 & 65 & 94 & 40.6 & 5.9 & 24.2 & 151.2 & 36.1 & 361 & 2.9 \\
\hline Collect fuel Field & 0.38 & $00: 30: 21$ & 22 & 137 & 69 & 101 & 51.3 & 8.4 & 28.6 & 910.5 & 217.5 & 435 & 3.5 \\
\hline Carry out Field & 0.42 & 00:06:55 & 1 & 114 & 60 & 97 & 37.5 & 2.7 & 26.1 & 152.5 & 36.4 & 312 & 2.5 \\
\hline Burn wood Field & 0.44 & 03:13:13 & 13 & 112 & 48 & 70 & 35.6 & -4.8 & 9.1 & 1920.8 & 458.8 & 143 & 1.1 \\
\hline Hike in Forest & 0.4 & 00:07:25 & 3 & 97 & 72 & 84 & 26.1 & 10.3 & 17.9 & 135.3 & 32.3 & 277 & 2.2 \\
\hline Collect fuel Forest & 0.29 & $00: 31: 58$ & 5 & 129 & 66 & 101 & 46.3 & 6.5 & 28.6 & 915 & 218.5 & 410 & 3.3 \\
\hline Carry out Forest & 0.55 & 00:08:06 & 15 & 128 & 64 & 103 & 45.6 & 5.3 & 29.9 & 218.5 & 52.2 & 392 & 3.2 \\
\hline Burn wood Forest & 2.84 & 03:50:12 & 129 & 127 & 54 & 74 & 45 & -1 & 11.6 & 2905.2 & 693.9 & 181 & 1.5 \\
\hline 30 min rest & 0 & 00:30:06 & 0 & 86 & 61 & 69 & 19.1 & 3.4 & 8.4 & 259.8 & 62.1 & 124 & 1 \\
\hline
\end{tabular}


Supplemental Table 3: Data collected from Volunteer 3 (male, 30yo)

\begin{tabular}{|c|c|c|c|c|c|c|c|c|c|c|c|c|c|}
\hline Action & $\begin{array}{c}\text { distance } \\
(\mathrm{km}) \\
\end{array}$ & $\begin{array}{c}\text { time elapsed } \\
\text { (h:m:s) }\end{array}$ & $\begin{array}{l}\text { elevation } \\
\text { gain }(\mathrm{m})\end{array}$ & $\max \mathrm{hr}$ & $\min \mathrm{hr}$ & median hr & $\begin{array}{c}\max \\
\mathrm{kJ} / \mathrm{min} \\
\end{array}$ & $\begin{array}{c}\min \\
\mathrm{kJ} / \mathrm{min} \\
\end{array}$ & $\begin{array}{l}\text { median } \\
\mathrm{kJ} / \mathrm{min}\end{array}$ & total kJ & $\begin{array}{l}\text { total } \\
\text { kcal }\end{array}$ & $\begin{array}{l}\text { kcal/ } \\
\text { hour }\end{array}$ & $\begin{array}{l}\text { "MET" } \\
\text { value } \\
\end{array}$ \\
\hline Hike in Meadow & 2.89 & $00: 56: 23$ & 187 & 185 & 74 & 123 & 19.6 & 9.6 & 40.5 & 2359.6 & 563.9 & 604 & 3.0 \\
\hline Collect fuel Meadow & 0.5 & $00: 30: 21$ & 11 & 164 & 73 & 133 & 66.3 & 8.9 & 46.8 & 1433.4 & 342.6 & 685 & 3.3 \\
\hline Hike out Meadow & 0.91 & $00: 13: 58$ & 11 & 126 & 73 & 108 & 42.3 & 8.9 & 31 & 400.6 & 95.7 & 442 & 2.2 \\
\hline Hike in Field & 0.23 & 00:06:14 & 18 & 141 & 102 & 115 & 51.9 & 27.2 & 35.4 & 238.4 & 57 & 570 & 2.8 \\
\hline Collect fuel Field & 0.65 & $00: 30: 42$ & 33 & 196 & 97 & 134 & 86.5 & 24.1 & 47.4 & 1513.4 & 361.7 & 723 & 3.5 \\
\hline Carry out Field & 0.42 & 00:08:29 & 1 & 149 & 80 & 139 & 56.9 & 13.3 & 50.6 & 394.1 & 94.2 & 707 & 3.4 \\
\hline Burn wood Field & 0 & 03:03:07 & 0 & 144 & 49 & 89 & 53.7 & -6.2 & 19 & 3578 & 855.2 & 280 & 1.4 \\
\hline Hike in Forest & 0.31 & 00:05:19 & 3 & 110 & 75 & 90 & 32.3 & 10.2 & 19.7 & 109.2 & 26.1 & 313 & 1.5 \\
\hline Collect fuel Forest & 0.12 & $00: 30: 23$ & 0 & 171 & 84 & 128 & 70.7 & 15.9 & 43.6 & 1310.3 & 313.2 & 626 & 3.1 \\
\hline Carry out Forest & 0.43 & 00:08:14 & 6 & 155 & 83 & 134 & 60.7 & 15.2 & 47.4 & 359.9 & 86 & 645 & 3.1 \\
\hline Burn wood Forest & 1.03 & 03:35:19 & 49 & 135 & 48 & 86 & 48 & -6.8 & 17.1 & 4422.1 & 1056.9 & 295 & 1.4 \\
\hline 30 min rest & 0 & 00:30:43 & 0 & 98 & 67 & 80 & 24.7 & 5.2 & 13.4 & 428.5 & 102.4 & 205 & 1.0 \\
\hline
\end{tabular}


Supplemental Table 4: Food needed to match costs, based on USDA values

\begin{tabular}{|c|c|c|c|c|c|c|c|c|c|c|c|}
\hline Food Type & $\begin{array}{l}\text { Weight of } \\
\text { unit }\end{array}$ & $\begin{array}{l}\text { Size of } \\
\text { unit }(\mathrm{cm})\end{array}$ & $\begin{array}{l}\text { USDA raw } \\
\text { values (kJ / } \\
100 \mathrm{~g})\end{array}$ & $\begin{array}{l}\text { USDA } \\
\text { cooked } \\
\text { values (kJ / } \\
100 \mathrm{~g})\end{array}$ & $\begin{array}{l}\text { benefit } \\
\text { estimate } \\
\text { USDA } \\
\text { (kJ / 100g) }\end{array}$ & $\begin{array}{l}\text { minimum } \\
\text { cost based } \\
\text { on HR }\end{array}$ & $\begin{array}{l}\text { maximum } \\
\text { cost based } \\
\text { on HR }\end{array}$ & $\begin{array}{l}\text { weight } \\
\text { needed to } \\
\text { outweigh } \\
\text { min costs } \\
\text { (g) }\end{array}$ & $\begin{array}{l}\text { weight } \\
\text { needed to } \\
\text { outweigh } \\
\text { max costs } \\
\text { (g) }\end{array}$ & $\begin{array}{l}\text { number of } \\
\text { units } \\
\text { needed to } \\
\text { outweigh } \\
\text { min costs }\end{array}$ & $\begin{array}{l}\text { number of } \\
\text { units } \\
\text { needed to } \\
\text { outweigh } \\
\text { max costs }\end{array}$ \\
\hline Deer & 100 & $8 \times 8 \times 2$ & 502 & 661 & 159 & 2746 & 5043 & 1727 & 3172 & 17 & 32 \\
\hline Caribou & 100 & $8 \times 8 \times 2$ & 531 & 699 & 168 & 2746 & 5043 & 1635 & 3002 & 16 & 30 \\
\hline Rabbit & 100 & $8 \times 8 \times 2$ & 477 & 724 & 247 & 2746 & 5043 & 1112 & 2042 & 11 & 20 \\
\hline Salsify & 120 & $\begin{array}{c}30 \times 3 \\
\text { (diameter) }\end{array}$ & 343 & 284 & -59 & 2746 & 5043 & - & - & - & - \\
\hline Arrowhead & 12 & $\begin{array}{c}2 \times 3 \\
\text { (diameter) }\end{array}$ & 414 & 326 & -88 & 2746 & 5043 & - & - & - & - \\
\hline $\begin{array}{l}\text { Burdock } \\
\text { root }\end{array}$ & 160 & $\begin{array}{c}50 \times 3 \\
\text { (diameter) }\end{array}$ & 302 & 369 & 67 & 2746 & 5043 & 4099 & 7527 & 26 & 47 \\
\hline Carrot & 60 & $\begin{array}{c}17 \text { x } 3 \\
\text { (diameter) }\end{array}$ & 173 & 147 & -26 & 2746 & 5043 & - & - & - & - \\
\hline Tiger nut & 0.7 & $\begin{array}{c}1 \times 1 \\
\text { (diameter) }\end{array}$ & 1706 & - & - & 2746 & 5043 & - & - & - & - \\
\hline
\end{tabular}

Energetic information for all food items except the tiger nut was acquired from the US Department of Agriculture Food Composition Database (US

590 Department of Agriculture, Agricultural Research Service, Nutrient Data Laboratory, 2015). Information for the tiger nut was provided by the Spanish Food Composition database (Spanish Agency of Health and Nutrition, n.d.), which unfortunately does not provide estimates for the energy of the cooked food. 
Supplemental Table 5: Food needed to match costs, based on energetic costs of digestion of raw and cooked food by pythons

\begin{tabular}{|c|c|c|c|c|c|c|c|c|c|c|c|c|}
\hline & $\begin{array}{l}\text { weight } \\
\text { of unit } \\
\text { (g) }\end{array}$ & $\begin{array}{l}\text { size of } \\
\text { unit }(\mathrm{cm})\end{array}$ & $\begin{array}{l}\text { USDA } \\
\text { raw } \\
\text { values }(\mathrm{kJ} \\
\text { per } 100 \mathrm{~g})\end{array}$ & $\begin{array}{l}\text { python } \\
\text { raw } \\
\text { values (kJ } \\
\text { per 100g) }\end{array}$ & $\begin{array}{l}\text { python } \\
\text { cooked } \\
\text { values (kJ } \\
\text { per 100g) }\end{array}$ & $\begin{array}{l}\text { benefit } \\
\text { estimate } \\
\text { python } \\
\text { (kJ per } \\
100 \mathrm{~g})\end{array}$ & $\begin{array}{l}\text { minimum } \\
\text { cost }(\mathrm{kJ})\end{array}$ & $\begin{array}{l}\text { maximum } \\
\text { cost }(\mathrm{kJ})\end{array}$ & $\begin{array}{l}\text { weight } \\
\text { needed to } \\
\text { outweigh } \\
\text { min costs } \\
\text { (g) }\end{array}$ & $\begin{array}{l}\text { weight } \\
\text { needed to } \\
\text { outweigh } \\
\text { max costs } \\
\text { (g) }\end{array}$ & $\begin{array}{l}\text { number } \\
\text { units } \\
\text { needed to } \\
\text { outweigh } \\
\text { min costs }\end{array}$ & $\begin{array}{l}\text { number } \\
\text { units } \\
\text { needed to } \\
\text { outweigh } \\
\text { max costs }\end{array}$ \\
\hline Deer & 100 & $8 \times 8 \times 2$ & 502 & 316.26 & 376.5 & 60.24 & 2746 & 5043 & 4558 & 8372 & 46 & 84 \\
\hline Caribou & 100 & $8 \times 8 \times 2$ & 531 & 334.53 & 398.25 & 63.72 & 2746 & 5043 & 4309 & 7914 & 43 & 79 \\
\hline Rabbit & 100 & $8 \times 8 \times 2$ & 477 & 300.51 & 357.75 & 57.24 & 2746 & 5043 & 4797 & 8810 & 48 & 88 \\
\hline Salsify & 120 & $\begin{array}{c}30 \times 3 \\
\text { (diameter) }\end{array}$ & 343 & 216.09 & 257.25 & 41.16 & 2746 & 5043 & 6672 & 12252 & 56 & 102 \\
\hline Arrowhead & 12 & $\begin{array}{c}2 \times 3 \\
\text { (diameter) }\end{array}$ & 414 & 260.82 & 310.5 & 49.68 & 2746 & 5043 & 5527 & 10151 & 461 & 846 \\
\hline $\begin{array}{l}\text { Burdock } \\
\text { root }\end{array}$ & 160 & $\begin{array}{c}50 \times 3 \\
\text { (diameter) }\end{array}$ & 302 & 190.26 & 226.5 & 36.24 & 2746 & 5043 & 7577 & 13916 & 47 & 87 \\
\hline Carrot & 60 & $\begin{array}{c}17 \times 3 \\
\text { (diameter) }\end{array}$ & 173 & 108.99 & 129.75 & 20.76 & 2746 & 5043 & 13227 & 24292 & 220 & 405 \\
\hline Tiger nut & 0.7 & $\begin{array}{c}1 \text { x } 1 \\
\text { (diameter) }\end{array}$ & 1706 & 1074.78 & 1279.5 & 204.72 & 2746 & 5043 & 1341 & 2463 & 1916 & 3519 \\
\hline
\end{tabular}


Supplemental Table 6: Food needed to match costs, based on feeding trial values of costs of digestion for humans (cooked foods) and animals (raw foods)

\begin{tabular}{|c|c|c|c|c|c|c|c|c|c|c|c|c|}
\hline Food item & $\begin{array}{l}\text { weight } \\
\text { of unit } \\
\text { (g) }\end{array}$ & $\begin{array}{l}\text { size of } \\
\text { unit }(\mathrm{cm})\end{array}$ & $\begin{array}{l}\text { USDA } \\
\text { raw } \\
\text { values (kJ } \\
\text { per 100g) }\end{array}$ & $\begin{array}{l}\text { feeding } \\
\text { trial raw } \\
\text { values }(\mathrm{kJ} \\
\text { per } 100 \mathrm{~g})\end{array}$ & $\begin{array}{l}\text { feeding } \\
\text { trial } \\
\text { cooked } \\
\text { values (kJ } \\
\text { per 100g) }\end{array}$ & $\begin{array}{l}\text { benefit } \\
\text { estimate } \\
\text { feeding } \\
\text { trials (kJ } \\
\text { per } 100 \mathrm{~g})\end{array}$ & $\begin{array}{l}\text { minimum } \\
\text { cost }(\mathrm{kJ})\end{array}$ & $\begin{array}{l}\text { maximum } \\
\text { cost }(\mathrm{kJ})\end{array}$ & $\begin{array}{l}\text { weight } \\
\text { needed to } \\
\text { outweigh } \\
\text { min costs } \\
\text { (g) }\end{array}$ & $\begin{array}{l}\text { weight } \\
\text { needed to } \\
\text { outweigh } \\
\text { max costs } \\
\text { (g) }\end{array}$ & $\begin{array}{l}\text { number } \\
\text { units } \\
\text { needed to } \\
\text { outweigh } \\
\text { min costs }\end{array}$ & $\begin{array}{l}\text { number } \\
\text { units } \\
\text { needed to } \\
\text { outweigh } \\
\text { max costs }\end{array}$ \\
\hline Deer & 100 & $8 \times 8 \times 2$ & 502 & 452.302 & 465.856 & 13.554 & 2746 & 5043 & 20260 & 37207 & 203 & 372 \\
\hline Caribou & 100 & $8 \times 8 \times 2$ & 531 & 478.431 & 492.768 & 14.337 & 2746 & 5043 & 19153 & 35175 & 192 & 352 \\
\hline Rabbit & 100 & $8 \times 8 \times 2$ & 477 & 429.777 & 442.656 & 12.879 & 2746 & 5043 & 21322 & 39157 & 213 & 392 \\
\hline Salsify & 120 & $\begin{array}{c}30 \times 3 \\
\text { (diameter) }\end{array}$ & 343 & 309.043 & 318.304 & 9.261 & 2746 & 5043 & 29651 & 54454 & 247 & 454 \\
\hline Arrowhead & 12 & $\begin{array}{c}2 \times 3 \\
\text { (diameter) }\end{array}$ & 414 & 373.014 & 384.192 & 11.178 & 2746 & 5043 & 24566 & 45115 & 2047 & 3760 \\
\hline $\begin{array}{l}\text { Burdock } \\
\text { root }\end{array}$ & 160 & $\begin{array}{c}50 \times 3 \\
\text { (diameter) }\end{array}$ & 302 & 272.102 & 280.256 & 8.154 & 2746 & 5043 & 33677 & 61847 & 210 & 387 \\
\hline Carrot & 60 & $\begin{array}{c}17 \times 3 \\
\text { (diameter) }\end{array}$ & 173 & 155.873 & 160.544 & 4.671 & 2746 & 5043 & 58788 & 107964 & 980 & 1799 \\
\hline Tiger nut & 0.7 & $\begin{array}{c}1 \times 1 \\
\text { (diameter) }\end{array}$ & 1706 & 1537.106 & 1583.168 & 46.062 & 2746 & 5043 & 5962 & 10948 & 8516 & 15640 \\
\hline
\end{tabular}


